\title{
A CONSERVAÇÃO DA PAISAGEM NA PERSPECTIVA DE UM SISTEMA DE ESPAÇOS LIVRES PÚBLICOS DO RECIFE
}

\author{
THE CONSERVATION OF THE LANDSCAPE IN THE PERSPECTIVE OF A PUBLIC OPEN \\ SPACES SYSTEM IN RECIFE
}

\author{
Ana Rita Sá Carneiro \\ Arquiteta, PhD, professora da graduação e da pós-graduação do Departamento de Arquitetura e \\ Urbanismo MDU/UFPE e coordenadora do Laboratório da Paisagem. \\ e-mail: anaritacarneiro@hotmail.com \\ Mirela Duarte \\ Bolsista PIBIC CNPq/UFPE, grupo de pesquisa Jardins de Burle Marx - Departamento de Arquitetura \\ e Urbanismo/UFPE. \\ e-mail: mireladuarte@gmail.com
}

Eliábi A. Marques

Bolsista PIBIC CNPq/UFPE, grupo de pesquisa Jardins de Burle Marx - Departamento de Arquitetura e Urbanismo/UFPE.

e-mail: eliabimarques@gmail.com

\section{RESUMO}

O artigo mostra a inter-relação do estudo dos espaços livres públicos com o estudo da paisagem urbana do Recife, segundo uma visão sistêmica. Essa relação se define no momento da análise histórica da paisagem do sítio e, portanto, dos ecossistemas naturais - rios, restinga e manguezal, e mata atlântica - a qual, aos poucos, foi sendo ocupada. Esse foi o método escolhido para se compreender a morfologia dos espaços livres, os diferentes tipos e o que se preserva como patrimônio natural e cultural. Atualmente, as águas permanecem por todo o território em menor proporção como rios, lagoas e canais. As unidades de conservação se apresentam de forma articulada e contínua na parte oeste limite da cidade e, na malha urbana, estão os espaços isolados como parques e praças, podendo se interligar pela arborização urbana e tratamento paisagístico de margens de rios e canais.

Palavras-chave: História, sistema, espaços livres, paisagem, conservação.

\begin{abstract}
This paper presents the relationship between the study of public open spaces and the urban landscape in Recife, according a systemic vision. This relationship is defined with the historical analysis of the natural ecosystems in the site landscape such as rivers, coast vegetation and mangrove, and the atlantic forest, which was occupied by the time. This method was chosen to understand the morphology of open spaces, its typology and which is preserved as natural and cultural heritage. Nowadays, urban water remains in the city space as rivers, lagoons and canals. Preserved natural areas present as a system in the west part of the city and in the urban framework are the isolated open spaces as parks and squares, which can be interrelated in a future urban plan by tree planting in the streets, and landscape design of the rivers and canals margins.
\end{abstract}

Key words: History, system, open spaces, landscape, conservation. 


\section{INTRODUÇÃO}

O estudo dos espaços livres públicos do Recife se iniciou em 1998 com a identificação da tipologia e a conceituação dos diferentes tipos, a exemplo de: unidades de conservação, faixa de praia, parques, praças, jardins, pátios, largos, quadras polivalentes e cemitérios (SÁ CARNEIRO; MESQUITA, 2000). Esse estudo tomou como base física as seis regiões político-administrativas em que está dividida a cidade, nas quais os espaços livres foram considerados elementos integrantes da paisagem urbana. Foram identificadas três linhas de força da paisagem: o rio Capibaribe, o litoral e as áreas remanescentes da Mata Atlântica.

A identificação dos espaços livres foi revelando, aos poucos, detalhes da paisagem recifense e pronunciando a necessidade de entender o processo de formação dessa paisagem urbana que hoje se apresenta. Consolidou-se a decisão em investigar a história da paisagem, levando em consideração os ecossistemas naturais do sítio e sua ocupação ao longo do tempo para justificar a existência dos espaços livres públicos atuais. Seguiu-se a leitura de mapas e iconografias para identificar unidades de paisagem que permaneceram, apesar do aumento acelerado das construções, extrapolando as previsões dos planos urbanísticos. A história da paisagem passou a ser o elemento-chave para a caracterização de unidades de paisagem contendo espaços edificados e espaços livres.

O Recife tem uma paisagem distinta pela presença abundante da água - rios e canais, de manguezal e áreas remanescentes da Mata Atlântica, de praças históricas e dos primeiros jardins projetados pelo paisagista Roberto Burle Marx. Esses elementos de valor cultural vêm se descaracterizando dia após dia e sofrendo sérias ameaças de extinção, uma vez que a prioridade vem sendo dada à concentração de construções verticais sem a menor preocupação de escala, proporção e harmonia com os espaços livres públicos existentes. São barreiras construtivas de elementos isolados os quais impedem a ventilação e a visualização, quebrando a continuidade da paisagem.

Na maioria das vezes, a morfologia dos espaços livres públicos mostra espaços isolados sem articulação com os demais, diferenciando-se apenas aqueles pertencentes aos bairros mais antigos que fazem pulsar a vida do lugar. A possibilidade de uma articulação foi acenada utilizando-se a abordagem sistêmica da paisagem, a qual permitiu visualizar uma ligação entre os diferentes espaços livres, a partir dos elementos lineares como as margens de rios e canais - atualmente, sinônimos de esgoto e sujeira.

Outro ponto a emergir na caracterização dos espaços livres públicos foi a condição de ser "público", ou seja, de um espaço do público, quando então a discussão passa para a esfera política de criação dos espaços pelas instituições e de sua utilização pelos usuários. A existência marcante dos campos de pelada como espaços livres potenciais na pesquisa Espaços livres do Recife (2000), explica, de certo modo, a falta de espaços livres nas áreas pobres.

A interpretação da paisagem pela análise da ocupação urbana, partindo dos ecossistemas naturais, identificou uma maior ou menor permanência de elementos naturais 
combinados com os elementos construídos, constituindo as unidades de paisagem de hoje, portanto, partes de um sistema. A identificação das unidades de paisagem cultural se apoiou no Protótipo de Catálogo de Paisagens (Prototipus de Catàlog de Paisatge, 2006), elaborado pelo Observatório da Paisagem de Barcelona.

\section{METODOLOGIA: CONCEITO E HISTÓRIA DA PAISAGEM}

Uma das maneiras de interpretar a paisagem urbana é observar as fases da evolução da ocupação humana sobre os ecossistemas naturais - águas ribeirinhas e marítimas, restinga, manguezal e a Mata Atlântica. Isso significa partir do sistema natural para entender a formação paulatina de uma paisagem urbana, ou seja, do todo para as partes. Foi esse o princípio adotado pelo Laboratório da Paisagem da UFPE para compreender a formação da paisagem urbana do Recife, no intuito de identificar unidades de paisagem a serem conservadas para garantir as referências históricas na memória de seus habitantes.

Partimos da compreensão de, segundo Berque (1997), a consciência da paisagem nascer na poesia e na pintura, da observação e compreensão da própria natureza a qual conduz o modo de agir sobre ela. Então, é observando a beleza e a dinâmica da natureza que esta será respeitada e isto se refletirá na paisagem - significa não haver paisagem sem o sentimento-paisagem - dimensão artística. Por outro lado, a cultura caracteriza a paisagem, desde as construções evidentes até o patrimônio intelectual ali conservado. Cada paisagem desvela uma cultura de conteúdo material e imaterial, de formas visíveis e invisíveis - dimensão cultural (FERRIOLO, 2007, p. 44).

As unidades de paisagem são porções do território que caracterizam combinações específicas de componentes sociais e físicos constituídos ao longo da história com dinâmica própria, atrelados, também, ao sentimento de pertencimento da população com o local (Prototipus de Catàlog de Paisatge, 2006). Esses recortes significativos retêm atributos e valores a serem preservados porque perpetuaram, ao longo do tempo, as ações primitivas do homem na paisagem natural, no sítio, com determinado tipo de constituição física.

Entre essas paisagens que retêm valores culturais e patrimoniais e precisam ser protegidas no Recife estão os jardins projetados pelo paisagista Burle Marx, a marcarem a paisagem dos bairros com cenários de plantas regionais brasileiras desde 1935. Esses jardins estão sendo inventariados para a elaboração da justificativa da significância, visando ao tombamento nacional.

No propósito de identificar tais unidades, partiu-se para a leitura da paisagem do Recife, uma cidade criada das águas, do mar e dos rios, traço característico de sua fisionomia. $O$ caminho das águas, portanto, delineou o sentido de expansão da malha urbana, enveredando ao interior, onde se implantaram os engenhos com o verde das canas-de-açúcar, alterando a cobertura vegetal, original da Mata Atlântica.

São esses os primeiros elementos da paisagem do Recife, uma paisagem que foi sendo, aos poucos, ocupada e modificada pelo homem, ao estabelecer laços de convivência com o sítio, caracterizando um gesto de morar. 
Nessa mesma idéia, Pisón (2001) cita Victor Hugo, o qual afirmou "Uma coisa é o espetáculo dos Alpes, outra coisa é quem é o espectador". Isso quer dizer que, ainda segundo Pisón, o espetáculo do amanhecer repete-se, mas os espectadores não são os mesmos. E, assim, nossas representações se somam às dos outros para uma compreensão da morfologia da paisagem. Esta, portanto, documenta, de maneira acumulativa, as fases de sua construção, seu conteúdo histórico e a ação dos moradores. Enfim, Pisón afirma que a paisagem aparece combinada de uma estrutura, forma, função, elementos, dinâmica, unidades e conteúdo cultural. A paisagem é forma e sentimento, é o visível e o invisível, em que atuam o tempo e o espaço, portanto, contendo história e personagens.

$\bigcirc$ estudo da paisagem do Recife traz a possibilidade para sua conservação. Com isso se inicia um processo de construção de uma consciência paisagística que leve a uma demanda social do direito à paisagem. Em outras palavras, trata-se da implantação de uma cultura paisagística que reivindique paisagens cuidadas e conservadas como um direito (PISÓN, 2003).

Na busca para identificar as unidades de paisagem, adotou-se como indicadores os seguintes critérios: espaços densamente vegetados, sítios e praças históricas, em especial as praças projetadas pelo paisagista Burle Marx, os espaços com água - rios, lagoas, canais - e a distribuição desses espaços livres na malha urbana, ou seja, a morfologia resultante de uma pretensa articulação. Tais, critérios, basicamente, decorrem da história da ocupação e do que permaneceu na estrutura urbana quanto à vegetação e às águas. Isso mostra que nos espaços livres públicos estão muitos desses elementos naturais os quais permaneceram na paisagem.

Esses critérios são pontos de partida para a análise dos mapas e iconografias de épocas marcantes na história do Recife. Então, os mapas e as iconografias, além dos relatos de viajantes estrangeiros e de escritores são fontes que foram interpretadas para a leitura de uma paisagem da qual guardaram características até os dias atuais. Recorreu-se, também, a várias fontes de informação atualizadas para a análise dessa ocupação. Entre elas está o Mapa das Unidades Ambientais do Recife, de 1993, que diagnostica os diferentes tipos de relevo decorrentes das mudanças temporais e ação antrópica: o ambiente de morros, de planícies, de águas e do baixo estuário e do litoral.

Por sua vez, o Mapa dos Espaços Livres do Recife (SÁ CARNEIRO; MESQUITA, 2000) construído na pesquisa em 2000, que gerou a interpretação das linhas de força da paisagem, confirma padrões de traçados urbanos estruturadores e tipos diferentes de espaços livres nos quais predominam as praças e os campos de pelada. As linhas de força, elementos contínuos que reportam à paisagem de origem, assim se revelaram: um cordão verde de unidades de conservação a marcar o lado oeste do território da cidade, configurando o que ainda permanece com cobertura vegetal representativa, a serpentina do rio Capibaribe cortando a cidade de leste a oeste e a faixa do litoral.

Ainda, fortalecendo o componente social, o Mapa das Zonas Especiais de Interesse Social - ZEIS (PREFEITURA DO RECIFE, 2001) denuncia as áreas pobres em terrenos 
alagados, próximos a canais, ou com ausência de infra-estrutura, recortes diferenciados de paisagem.

Com essas informações atuais e recorrendo-se à leitura da ocupação do sítio ao longo da história, seria possível identificar unidades de paisagem em diferentes escalas que precisam ser preservadas para guardar as características históricas e significativas da paisagem dos bairros da cidade. Além disso, nem sempre as unidades de paisagem estão inseridas nas configurações dos bairros, pois, muitas vezes, saltam de seus limites e, ainda, dentro de duas unidades de paisagem pode surgir uma unidade de paisagem especial.

Nesse trabalho procurar-se-á caracterizar as unidades de paisagem na intenção de proteção, gestão e ordenação das paisagens a partir de uma visão sistêmica, o que ira refletir nos espaços livres. Essa caracterização poderá levar à elaboração de uma política de conservação da paisagem, no planejamento territorial do Recife, como marco conceitual metodológico e de procedimentos básicos. Desse modo, a conservação da paisagem constitui um instrumento de ordenação territorial que precisa de normas, diretrizes e recomendações para se efetivar. Esse instrumento irá permitir o macro-planejamento da paisagem urbana como item fundamental para preservar o caráter da paisagem urbana.

\section{INTENÇÕES DE ARTICULAR ESPAÇOS LIVRES NA HISTÓRIA DA PAISAGEM}

A análise da história da paisagem começa no período holandês, observando-se um conjunto de mapas de 1631, 1637, 1639, 1641 e 1644 (MENEZES, 1988). Antes dos holandeses havia uma pequena povoação junto do porto e alguns engenhos. Aos poucos, o porto foi se ampliando para o transporte do açúcar, no delta do Capibaribe, caminho natural direto para a Várzea do Capibaribe, segundo o estudo denominado Cidade do Amanhã, elaborado pela Fundação de Desenvolvimento da Região Metropolitana do Recife - FIDEM em 1987.

No mapa de 1644 está registrado o Plano Diretor da Cidade Maurícia, elaborado por Pieter Post, arquiteto da comitiva do conde Maurício de Nassau. Nele está evidente o desenho geométrico do traçado das vias e quadras sobre o terreno alagado aterrado, prevendo-se um sistema de canais e um sistema de defesa nos quais é possível distinguir como elementos da paisagem: os fortes, a ponte, o Parque de Friburgo, além da muralha protetora (Figura 1). $\bigcirc$ desenho do parque definia funções para os espaços e guardava uma disposição militar e defensiva como uma praça cívica. $\bigcirc$ jardim reunia um conjunto de flora e fauna do Brasil e outros países para criar um microcosmo da história natural do mundo (SILVA; ALCIDES, 2003).

O Plano Diretor da Cidade Maurícia, desenvolvido na ilha de Antonio Vaz, mostra essa preocupação com a estrutura urbana da cidade que inclui, como condição básica, um jardim situado em uma ponta da ilha, bastante favorável ao desfrute da paisagem em várias direções, atingindo, aproximadamente, 6,4 ha, algo inédito no Brasil até 
então. No plano de Pieter Post ficou evidenciada a utilização de um eixo estruturador estabelecido com a construção de uma ponte. Esse eixo é representado pela confluência natural vinda da linha de terra, desde o istmo, ligando Recife a Olinda, fazendo uma curva natural em direção à llha de Antônio Vaz, intensificada com a construção de uma ponte, unindo a porção de terra mais antiga ao continente (Figura 1).

Com a expulsão dos holandeses, muitas de suas construções foram destruídas, porém seu legado permaneceu e ajudou a definir uma idéia sobre cidade que até então não havia no Recife. Esse avanço no ordenamento do espaço, muito embora já se adotando a opção pelos aterros, orienta a futura expansão do território.

No século XIX a urbanização saiu dos bairros coligados: Recife, Santo Antonio, São José e Boa Vista e foi para o norte, pelo rio Beberibe; para o oeste, pelo rio Capibaribe; e, para o sul, pelo rio Jiquiá. Nesse momento, houve uma preocupação em operacionalizar os meios de transporte, bondes, vindos da Europa, impulsionada pela chegada da família real no Brasil, a qual disseminou, para as principais cidades litorâneas, o que se fazia na Corte (Rio de Janeiro) em termos de arquitetura, urbanismo e paisagismo. Com isso, começou a estabelecer-se o sistema de transporte junto do sistema viário na paisagem da cidade.

Por essa época, um dos espaços públicos mais freqüentados pelos habitantes era o cais, mantendo ainda a forte relação com as águas (Figura 2). E o adensamento construtivo já se fazia notar em face da exigüidade de terreno firme em meio a um conjunto de ilhas (Figura 3).

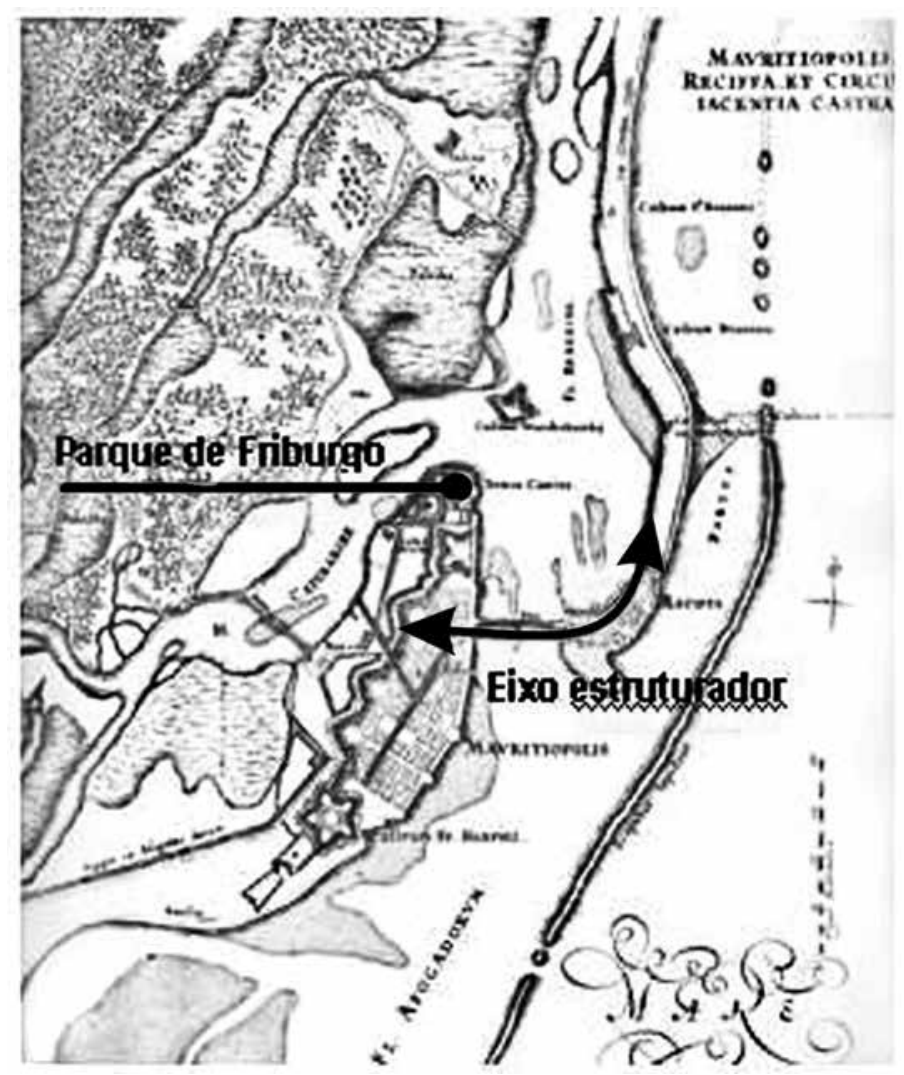

Figura 1: Planta do Plano Diretor do governo de Nassau (1644), editado pelo Laboratório da Paisagem

Fonte: Cidade do amanhã, Fidem (1987) 
A linha de força das águas do rio Capibaribe direcionou a implantação dos engenhos de açúcar que, por sua vez, originou os núcleos dos bairros. Isso fica mais evidente no mapa de 1906 elaborado por Douglas Fox (Figura 4). Percebe-se o eixo viário para o sul, outro para o lado norte e a expansão centralizada. Esse traçado já difere do desenho barroco holandês, mas os rios permanecem guiando os assentamentos.

No conjunto dos espaços livres ressaltam-se o cemitério de Santo Amaro, o terreno destinado ao Passeio Público 13 de Maio e o Campo das Princesas. No século XIX vários jardins foram construídos seguindo um plano de aformoseamento e embelezamento dirigido pelo conde da Boa Vista - praças, cais (ARRAIS, 2004). Nessa época já existiam os pátios das igrejas bastante freqüentados pela elite local, ou seja, não tinham o caráter de espaço público (ARRAIS, 2004, p. 220). Uma proposta para o Passeio Público 13 de Maio foi apresentada em 1860, na intenção de articular a área do futuro parque com o jardim do Campo das Princesas e com o rio Capibaribe.

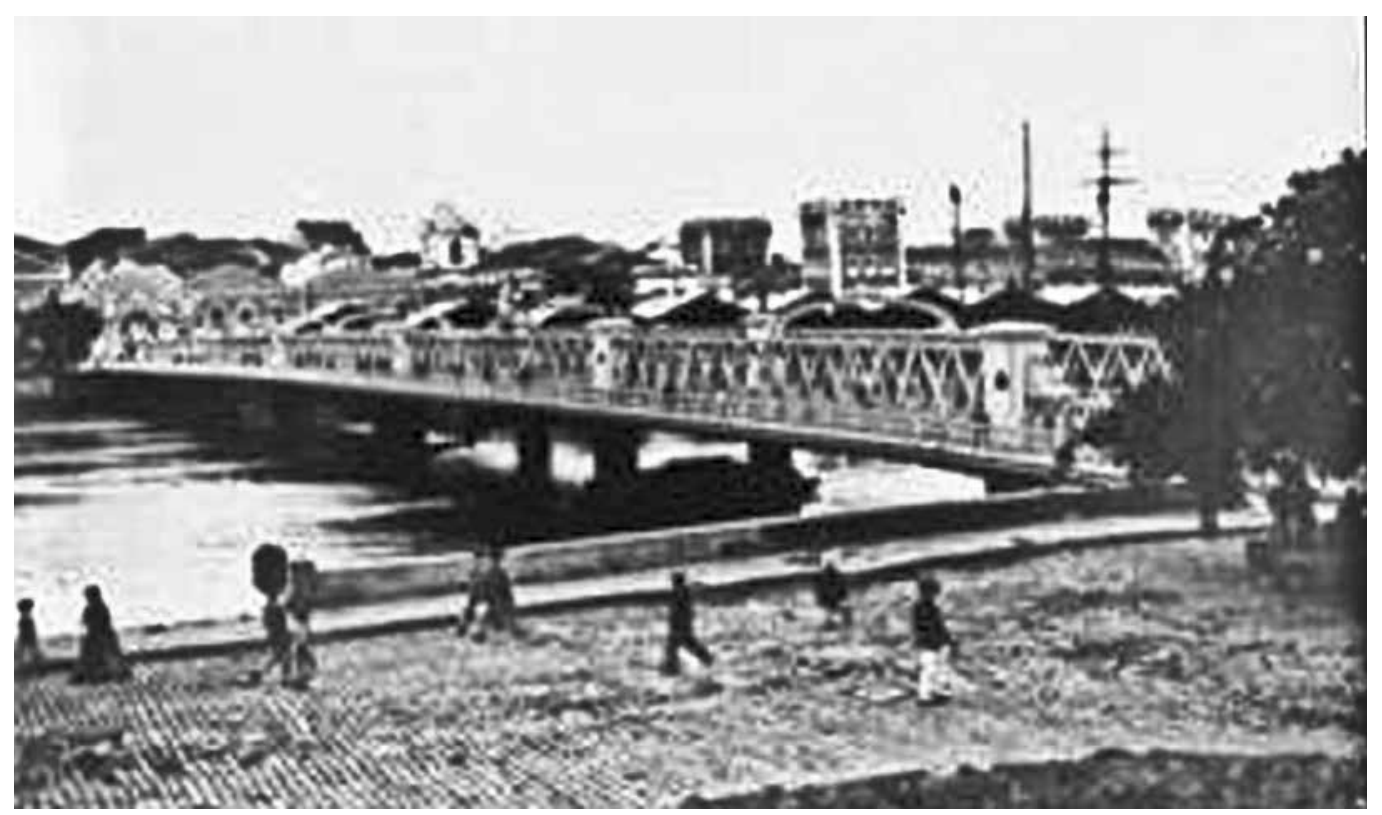

Figura 2: Vista do cais, espaço público de convivência com o rio Capibaribe Fonte: Arquivo Museu da Cidade do Recife Crédito: Fotógrafo não-identificado, c.a. 1890

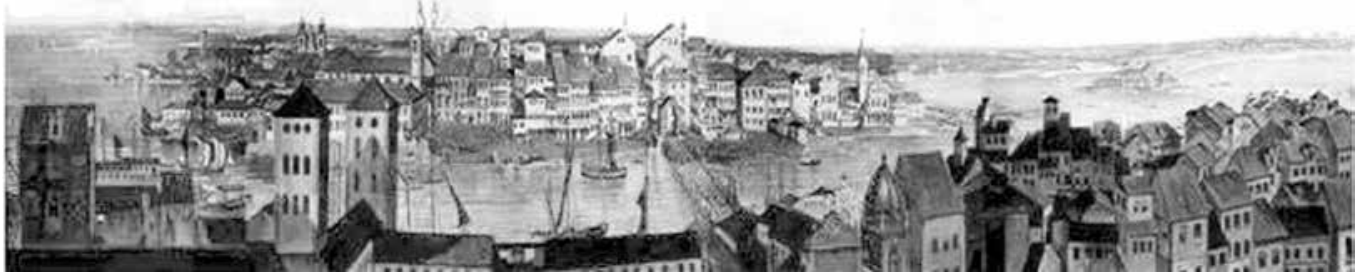

Figura 3: Vista geral da ilha de Antônio Vaz a partir do bairro do Recife Fonte: Arquivo Museu da Cidade do Recife

Crédito: Cromolitografia sobre tela de R. Schimdt, ativo no Brasil entre 1826 e 1832 
E, no início do século XX, os morros e áreas ribeirinhas começavam a ser ocupadas com as moradias espontâneas de antigos escravos, de onde surgem aglomerados fixos como o do morro da Conceição, hoje um referencial em participação popular.

As propostas para serviços urbanos se direcionam ao sistema de esgotos e de água encanada, ao sistema de circulação em vias públicas para automóveis e pedestres e sistema de canais para drenagem de águas pluviais. Nesse momento (1910) foi destaque o engenheiro sanitarista Francisco Saturnino de Brito, a planejar um sistema de esgotamento sanitário atrelado ao traçado urbano, uma infra-estrutura viável para uma futura metrópole. Nesse projeto ele procurou associar a necessidade de reserva de espaços livres de parques em áreas pantanosas, garantidas para o uso em momento posterior. Relacionou o crescimento urbano e espaços livres de recreação dentro dos princípios de assegurar a conservação dos espaços livres para um novo estágio.

No século XX aumentam as intenções de criar um Recife novo. Surgiram mais espaços livres: o Parque do Derby (1925), um empreendimento de grande porte que abrangia o parque e os lotes residenciais, o qual configurou o bairro do Derby, e outras praças então denominadas parques, acompanhando a expansão da cidade.

Novos espaços urbanos foram construídos para receber a população que deixava o centro da cidade, o qual passava a ser ocupado, principalmente, por estabelecimentos

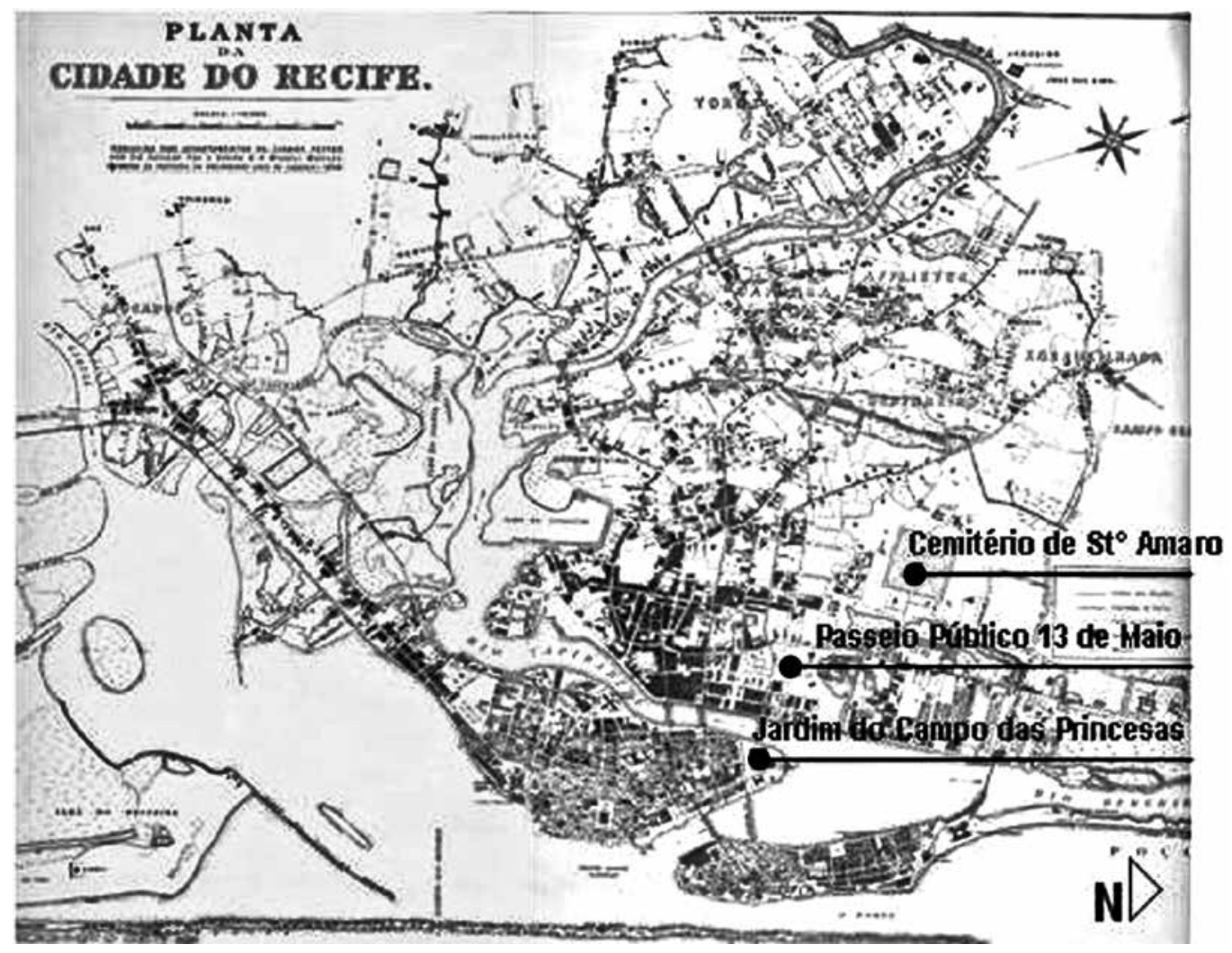

Figura 4: Mapa elaborado por Douglas Fox (1906), editado pelo Laboratório da Paisagem Fonte: Mapa cedido pela arquiteta Liana Mesquita 
comerciais. Esse direcionamento tem como base princípios higienistas da legislação urbanística em vigor no início do século XX (OUTTES, 1997), que estabelecia novas regras para construção de casas, exigindo ambientes abertos para o exterior, a fim de melhor arejar e iluminar os espaços internos diferentes das antigas construções do período colonial. Assim, novas moradias contendo jardins, quintais e recuos laterais foram criadas em terrenos afastados do centro urbano do Recife (Figura 5).

A cidade moderna continua sendo um parâmetro urbanístico, arquitetônico e paisagístico a seguir e, em 1935, assumiu o Setor de Parques e Jardins do Departamento de Arquitetura e Construção, o paisagista Roberto Burle Marx, o qual encontra uma cidade com vários espaços livres distribuídos na malha urbana, caracterizando as paisagens dos bairros, entre eles praças, pátios e largos interligados pelos rios e canais. Burle Marx observa bastante a paisagem local e apresenta 14 propostas de jardins públicos para a cidade como parte de um "plano de aformoseamento (...) um plano de jardins uniformizado", em que o conjunto de jardins públicos deveria ser tratado não só no centro da cidade, mas também nos bairros residenciais (DIÁRIO DA TARDE, 1935).

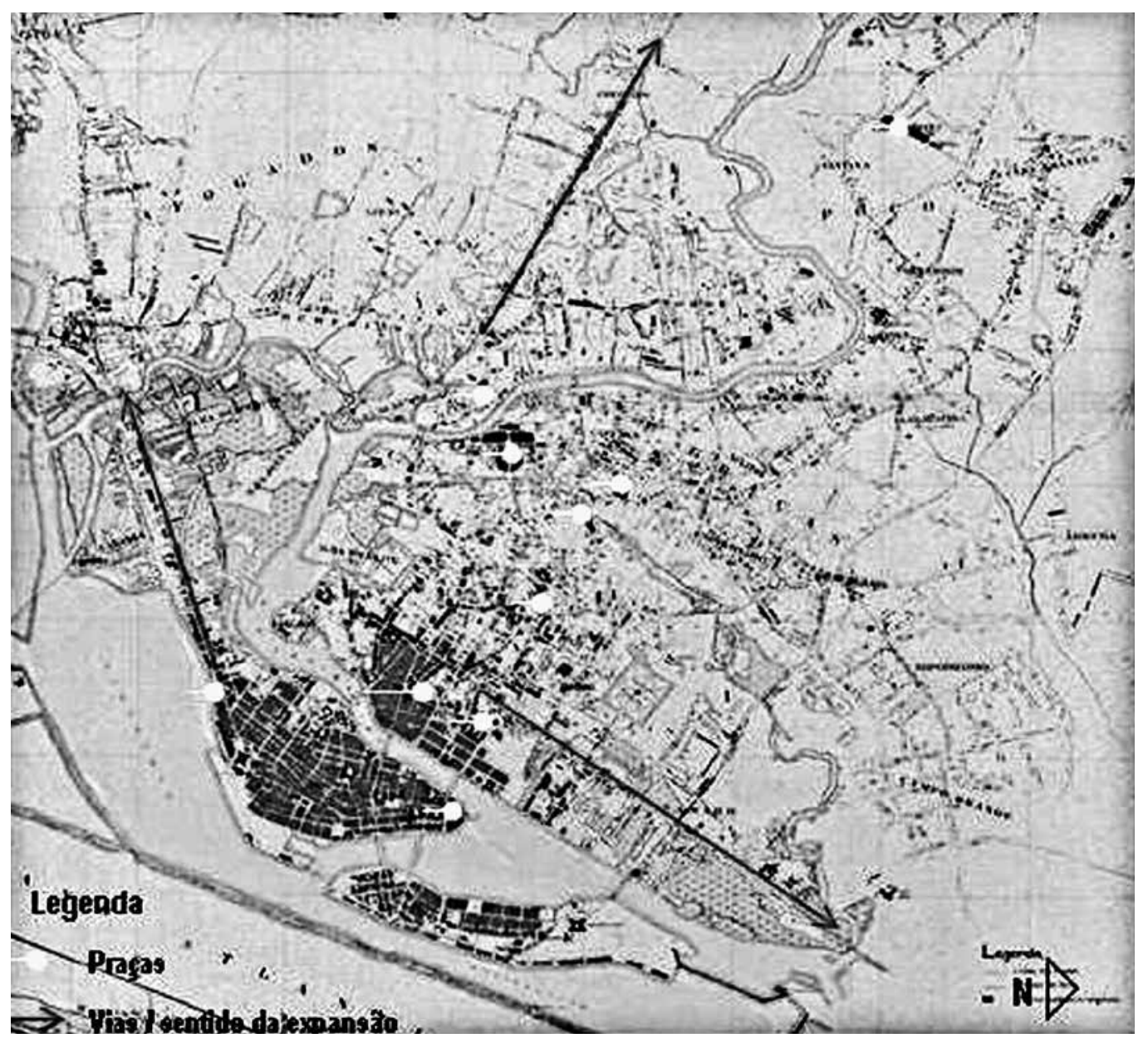

Figura 5: Mapa do Recife de 1932, editado pelo Laboratório da Paisagem, mostrando as praças e as zonas de expansão a partir da morfologia do rio Capibaribe

Fonte: Museu da Cidade do Recife 
nível de elaboração do mapa de 1932 pronuncia o rio Capibaribe como um vetor de expansão e as vias tronco como determinantes da configuração atual, aproximando a visualização do estado atual de urbanização. E o destaque dado aos espaços livres, apontando os núcleos dos bairros, parece acusar a relevância e a intenção de articulação entre eles. São os núcleos ainda existentes que precisam ser preservados para guardar um compromisso com a história da paisagem. É provável que, por tais motivos, muitas dessas áreas estejam protegidas como zonas especiais de preservação de sítios históricos - ZEPH, da lei de 1996, também atendendo à condição de unidades de paisagem.

Por volta de 1950 começam a estabelecer-se, em definitivo, algumas paisagens peculiares que podem ser denominadas unidades de paisagem e estão distribuídas em diversos pontos da cidade, a exemplo de: morro da Conceição, Brasília Teimosa, Poço da Panela, o centro da Várzea, praça da República, o Campo das Princesas e o bairro do Derby. E as águas atuando como vetor de expansão e de identificação das unidades de paisagem.

\section{A MORFOLOGIA DA PAISAGEM E O SISTEMA DE ESPAÇOS LIVRES PÚBLICOS}

○ sítio onde se desenvolveu a cidade do Recife é caracterizado pela existência de grande abundância de água e tipos diferenciados de relevo e vegetação. Trata-se, portanto, de uma complexa formação físico-geográfica que passa por regiões litorâneas, de baixo estuário, de planície e morros. Esses elementos naturais da cidade do Recife compõem o que hoje chamamos de Unidades Ambientais (ATLAS AMBIENTAL DA CIDADE DO RECIFE, 2000).

ambiente litorâneo demarca uma longa faixa a leste da cidade, e, em sua transição com o ambiente do baixo estuário, encontra-se a vegetação de restinga e mangue (Figura 6) por ser uma região encharcada, já que os rios estão mais próximos de seu encontro com o mar. $\bigcirc$ ambiente de planície concentra a maior área da cidade, onde os rios exercem maior importância social e encontra-se a vegetação de médio e grande portes da cidade, espécies típicas da Mata Atlântica (cores rosa e laranja). $\bigcirc$ ambiente de morro é o mais afastado do litoral e onde, ainda hoje, encontra-se a vegetação de maior porte e em maior abundância, remanescentes de espécies da Mata Atlântica.

Da identificação dos tipos de espaços livres na pesquisa de 2000 (SÁ CARNEIRO; MESQUITA, 2000) e de dados do estudo das unidades ambientais foi possível construir o Mapa das Linhas de Força da Paisagem, a apontar as linhas que estruturam a paisagem hoje - a faixa litorânea, o rio Capibaribe e o cordão verde das 25 unidades de conservação remanescentes da Mata Atlântica e, ao mesmo tempo, impulsiona a investigação da cartografia histórica em busca da evolução da dinâmica de ocupação do território da cidade (Figura 7).

O sistema natural de drenagem é formado pelas bacias hidrográficas dos principais rios da cidade: Capibaribe, Beberibe e Tejipió, que percorrem o Recife desde a região 
de morros até desaguarem no oceano (ATLAS AMBIENTAL DA CIDADE DO RECIFE, 2000). O rio Capibaribe recebe ainda maior atenção, pois representa uma linha de força por cortar a cidade de leste a oeste, passando com intensidade pelo ambiente de planície e afirmando sua importância histórica, cultural e social. Outros elementos marcantes na paisagem são os canais. $\bigcirc$ Recife possui 66 canais os quais se destacam aqueles denominados estruturadores: o canal Derby/Tacaruna, Vasco da Gama, o do Jordão, o do Setúbal e o do Cavouco (Figura 8). Quase todos os bairros, ricos ou

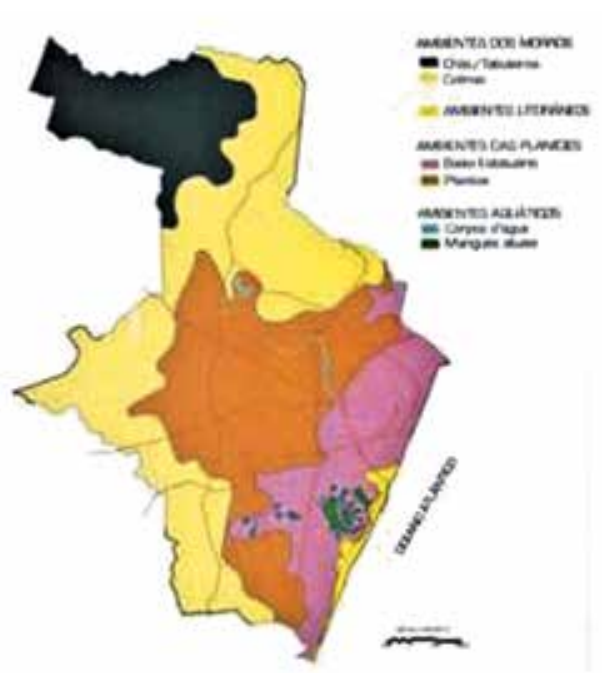

Figura 6: Mapa das Unidades Ambientais do Recife Fonte: SÁ CARNEIRO E MESQUITA, 2000

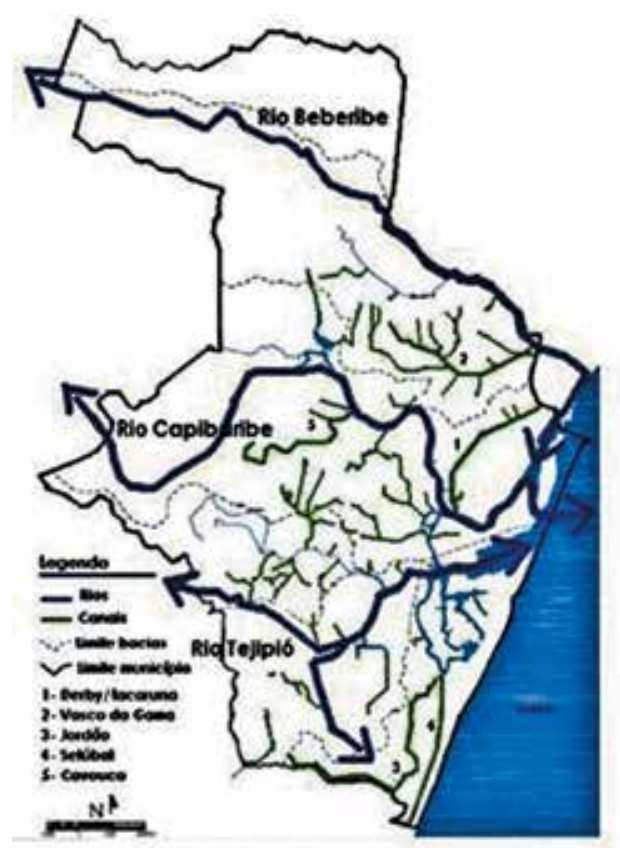

Figura 8: Sistema de Drenagem do Recife Fonte: Laboratório da Paisagem, 2008

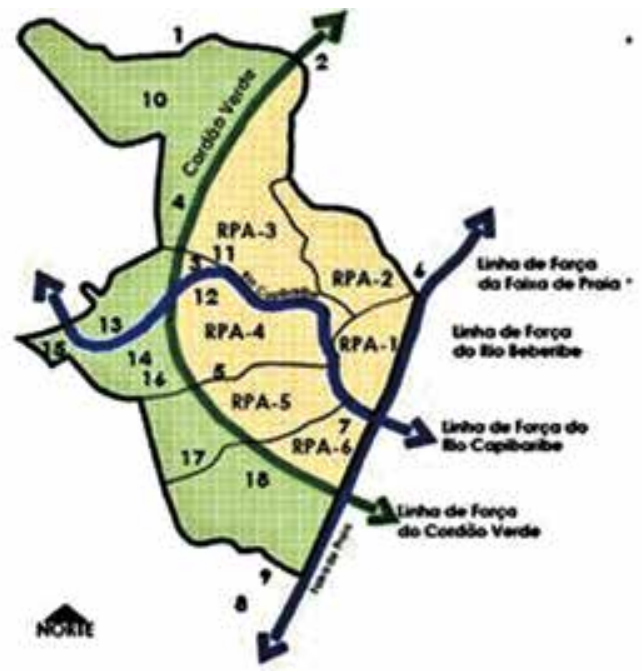

Figura 7: Mapa das Linhas de Força da Paisagem Fonte: SÁ CARNEIRO E MESQUITA, 2000

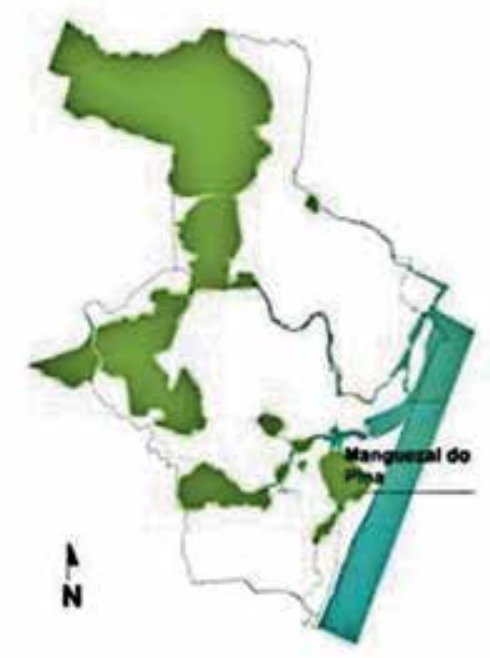

Figura 9: Unidades de Conservação do Recife Fonte: Laboratório da Paisagem, 2008 
pobres, antigos ou novos, são atravessados por rios, canais, riachos ou córregos; ou banhados por açudes como o de Apipucos, e lagoas como a do Araçá. Inclusive, há rios que viraram canal, como o antigo rio Água Fria, hoje canal do Arruda (Figura 9).

\section{4 - A LEGISLAÇÃO, O ESPAÇO PÚBLICO E A PAISAGEM}

traçado urbano dos bairros do Recife, de Santo Antonio e de São José guardou grande parte das definições do plano diretor da cidade maurícia. Até hoje se pode notar a permanência das ações originais dos primeiros habitantes, mantendo o caráter da paisagem histórica em seus pátios, largos, ruas estreitas, praças. Tais marcas foram preservadas com o instrumento das ZEPHs, a proteger áreas históricas, ou melhor, conjuntos históricos os quais também podem ser compreendidos como unidades de paisagem cultural (Figura 10). No mapa abaixo se vê as zonas históricas em cinza, os imóveis especiais de preservação em vermelho, os monumentos tombados estaduais em rosa e os monumentos tombados federais em amarelo.

As 33 ZEPHs mostram uma concentração de conjuntos urbanos e monumentos históricos concentrados na área de ocupação mais antiga. E essa seleção está apoiada em um dos sistemas mencionados, o sistema construído, e não apresenta relação com o sistema natural e até certo ponto com o espírito do lugar. Aquelas, na maioria, são áreas designadas por especialistas e carregam valores nacionais pertencentes a fatos históricos.

Mas não podemos esquecer das paisagens especiais que trazem um valor simbólico para segmentos da população de diferentes classes sociais, expressando traços da história da paisagem da cidade e precisam ser identificadas e preservadas. São registros históricos que guardam, em suas formas, características originais da ocupação

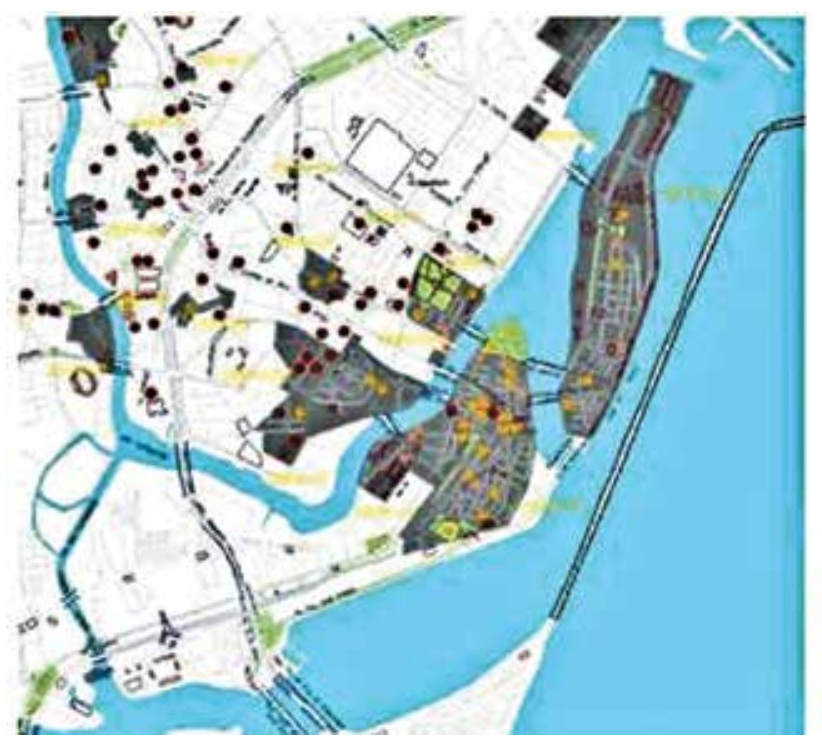

\section{CONVENÇŌES}

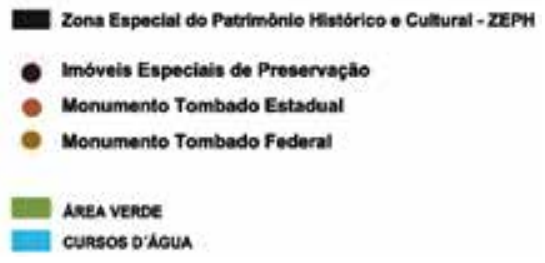

Figura 10: Mapa dos Bens Culturais Tombados e Preservados - Recorte, junho 2002

Fonte: PCR, Secretaria de Planejamento, Urbanismo e Meio Ambiente 
inicial e são mantidas e preservadas segundo princípios ecológicos e econômicos que garantam a sobrevivência.

Ao lado da legislação, concorre, para a conservação das paisagens e dos espaços livres, o envolvimento da população e a condição de espaço público como espaço do "público". A condição da esfera pública a qual, segundo Arendt (2003), refugia-se na dimensão política, é um componente de sustentabilidade social (CHEISURA, 2004). De um uso mais religioso nos pátios, com a criação das praças e parques, no final do século XIX, esses espaços passam a servir para encontros sociais, passeios, discursos políticos e apresentações musicais e, no rio, os banhos e passeios. Mas, a não ser por intermédio das ZEPHs, os espaços livres não dispõem de lei de proteção pela condição de espaço livre público e vegetado a exigir uma paisagem protegida também em seu entorno, de modo a assegurar a saudável convivência e uso desses espaços.

A relação paisagem/patrimônio não pode prescindir da existência de normas e regulamentação, baseada nos processos da conservação, fundamental para evitar descaracterizações. Assim, o objetivo da conservação não é congelar ou fossilizar as formas, mas mantê-las no tempo, contra a corrente a qual possa arruiná-la. Parece que a aplicação do conceito e de um regulamento da paisagem poderia permitir, acentuar ou incluir esse sentido de áreas protegidas as quais podem estender o território que não está ou, provavelmente, não poderá estar protegido por essas normas. Em outras palavras, é o direito à paisagem que precisa ser defendido por uma política de paisagem (PISÓN, 2003). As paisagens urbanas são as que expressam mais densamente essa história. A cidade-paisagem é a cidade-cultura. Na cidade de Barcelona, a Lei n. 8/2005 e o regulamento de proteção, gestão e ordenação da paisagem foram instituídos para preservar os valores naturais, patrimoniais, culturais e sociais, integrando a matéria "paisagem" no planejamento e nas políticas de ordenação territorial e urbanística. Isso significa verificar pontos na cidade que sejam marcantes para a visualização da paisagem, relacionando elementos naturais e construídos segundo parâmetros artísticos, ecológicos e educativos.

Ainda no sentido da preservação da paisagem, em maio de 2005 o Memorandum de Viena, resultado da reunião internacional do comitê da Unesco sobre o patrimônio mundial e a arquitetura contemporânea, registrou a necessidade de incluir uma nova categoria para a conservação dos sítios-patrimônios da humanidade. É a de paisagem urbana histórica, no sentido de proteger, de forma mais abrangente, a autenticidade e integridade dos sítios, conjuntos urbanos e monumentos isolados do impacto dos empreendimentos contemporâneos os quais, muitas vezes, ameaçam o patrimônio natural e cultural de valor excepcional, descaracterizando-o. Dessa forma, mostra a preocupação em manter o equilíbrio entre a implantação de novas construções, o patrimônio histórico como um processo de construção da paisagem cultural. A arquitetura da cidade precisa ser controlada pela busca da conservação de valores culturais.

Então, se, por um lado, há a ameaça das grandes edificações contemporâneas sobre os edifícios históricos, como mostra a Figura 11, onde se vê a cor marrom da maior densidade construtiva situada ao longo do rio Capibaribe e na praia de Boa 
Viagem, é preciso ter em mente a distribuição das áreas pobres, como mostra a Figura 12, para entender a cidade em sua totalidade. As áreas pobres estão distribuídas em todo o espaço da cidade e, por isso, devem ser incluídas no planejamento como um outro sistema.

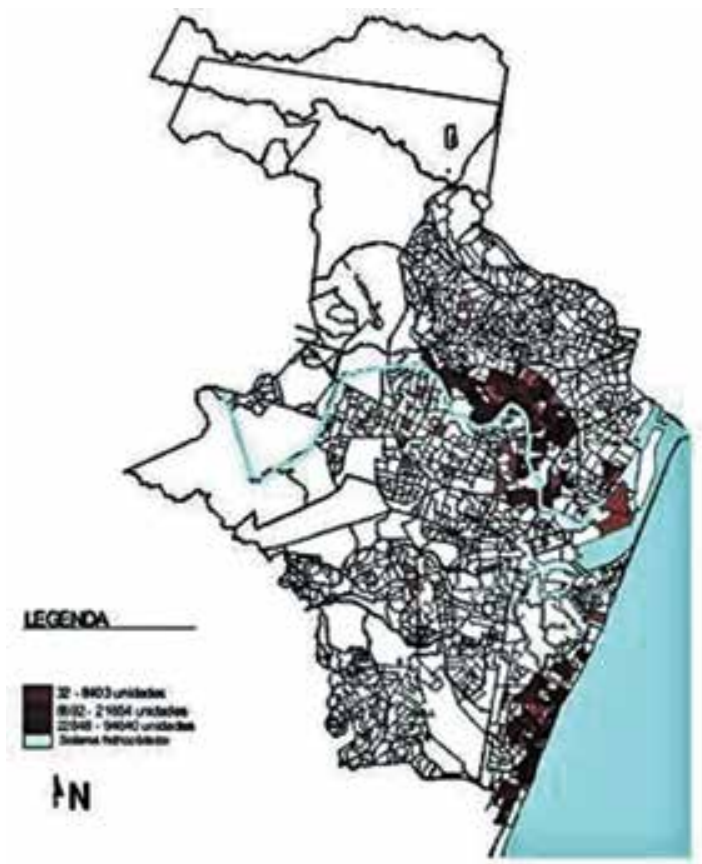

Figura 11: Índice de Verticalização

Fonte: Diagnóstico Urbano do Recife, SEPLAM/DIRBAM, 2005

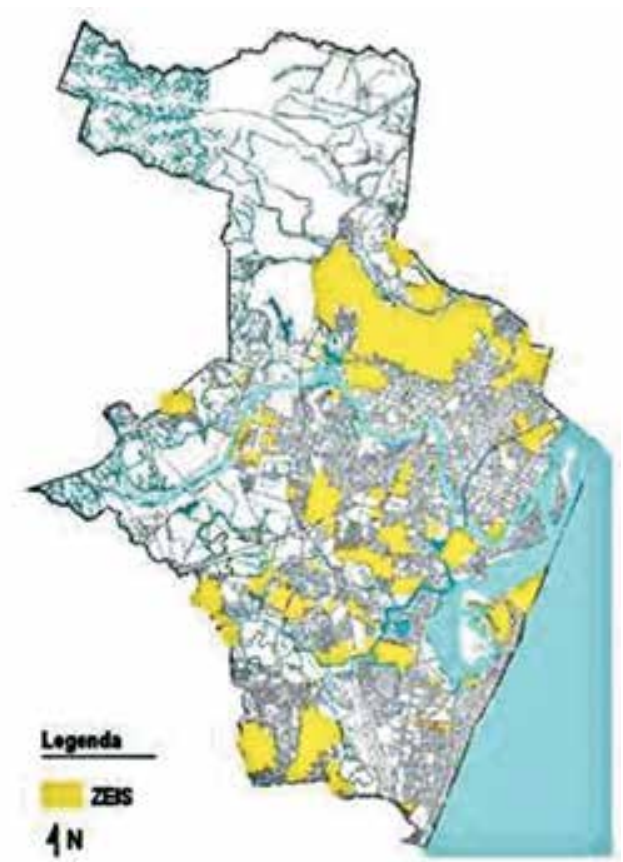

Figura 12: Mapa das ZEIS do Recife Fonte: PCR, 2001

\section{Bibliografia}

ANDRADE, Manuel C. de. O Recife entre as águas e os morros. Diário de Pernambuco, Recife, 09 mar. 1987. Recife: Problemática de uma metrópole de região subdesenvolvida. Recife: Editora Universitária, 1979.

ARENDT, Hannah. A condição humana. Rio de Janeiro: Forense Universitária, 2003.

ARRAIS, Raimundo. O pântano e o riacho. A formação do espaço público no Recife do século XIX. São Paulo: Humanistas/FFLCH-USP, 2004. 
BANDEIRA, Juliana. Os canais na paisagem do Recife: Por um sistema azul. Trabalho Final de Graduação - Faculdade de Arquitetura e Urbanismo, Universidade Federal de Pernambuco. Recife: UFPE, 2005.

BERQUE, Agustín. El Paisaje. Huesca: Arte y naturaleza. Actas del Segundo Curso Huesca, 23-27 setiembre, 1996. Espanha: Diputación de Huesca, 1997.

CASTRO, Josué de. Ensaios de geografia humana. São Paulo: Editora Brasiliense, 1969.

CHEISURA, A. The role of urban parks for the sustainable city. Landscape and Urban Planning, Nova York, n. 68, p. 129-138, 2004.

CORRÊA, Roberto; ROSENDHAL, Zeny. Paisagem, tempo e cultura. Rio de Janeiro: Ed. UERJ, 1998.

DIÁRIO DA TARDE. A vida da cidade. A reforma dos jardins públicos do Recife. Recife, 22 maio 1935.

FELIPPE, Ana Paula. Análise da Paisagem como Premissa para a Elaboração de Plano Diretor. Paisagem e Ambiente - Ensaios, São Paulo: FAUUSP, n. 16, p. 135-161, 2002.

FERRIOLO, Massimo V. Cultura. In: COLAFRANCESCHI, Daniela. Landscape + 100 palabras para habitarlo. Barcelona: Gustavo Gilli, 2007.

FIDEM. Cidade do amanhã. Recife: Fundação de Desenvolvimento da Região Metropolitana do Recife - Fidem, 1987.

FREYRE, G. Ingleses no Brasil: Aspectos da influência britânica sobre a vida, a paisagem e a cultura no Brasil. Rio de Janeiro: Livraria José Olympio, 1977.

JONG, Liesbeth de. The socio-spatial task of public spaces - The case study of the Horto d'el Rey in Olinda - Brasil. Master thesis - Wageningen University, Wageningen, The Netherlands, 2006.

MAIOR, Mário Souto; SILVA, Leonardo Dantas. O Recife: Quatro séculos de sua paisagem. Recife: Fundaj/Massangana/Prefeitura da cidade do Recife, 1992.

MELLO, José Antonio G. Tempo dos flamengos. Recife: Fundaj/Massangana, 1987.

MENEZES, José Luiz da Mota (Org.). Atlas Histórico Cartográfico do Recife. Recife: PCR/Massangana, 1988.

Arquitetura e urbanismo. In: HERKENHOFF, P. (Org.) O Brasil e os holandeses: 1630-1654. Rio de Janeiro: Sextanete Artes, 1999.

A cidade do Recife - Urbanismo lusitano e holandês. In: ANDRADE, M.; FERNANDES, E.; CAVALCANTI, S. (Org.). Tempo dos flamengos e outros tempos. Recife: Fundaj/Massangana, 1999.

MESQUITA, Liana. Memória dos verdes urbanos do Recife. Cadernos do Meio Ambiente, Recife: Prefeitura, v. 1, n. 1, 1998.

Programa de recuperação vegetal do Recife. Recife: Secretaria de Planejamento e Meio Ambiente - Prefeitura do Recife, 1994.

O BRASIL E OS HOLANDESES. Recife: Espaço Cultural Bandepe, 2000.

OUTTES, Joel. O Recife: Gênese do urbanismo 1927-1943. Recife: Massangana, 1997.

PEREIRA, Luz V. A leitura da imagem de uma área urbana como preparação para o planeamento/ação da sua reabilitação. Lisboa: Laboratório Nacional de Engenharia Civil, 1996.

PROTOTIPUS DE CATÀLEG DE PAISATGE. Bases conceptuals, metodològiques i procedimentals per elaborar els catàleg de paisatge de Catalunya. Olot i Barcelona, maig 2006. Disponível em: <http://www.catpaisatge.net/ cat/cataleg.php.

SÁ CARNEIRO, Ana Rita; MESQUITA Liana. Espaços livres do Recife. Recife: Prefeitura, 2000.

SILVA, Maria Angélica; ALCIDES, Melissa Mota. Collecting and Framing the Wilderness: The Garden of Johan Maurits (1604-79) in North-east Brazil. Garden History - The Journal of the Garden History Society, Londres, v. 30, 2003.

SPIRN, Anne Whiston.The language of landscape. New Haven; Londres: Yale University Press, 1998.

O jardim de granito. São Paulo: Edusp, 1995.

UNESCO. Operational Guidelines for the Implementation of the World Convention, 1992, Paris. Disponível em: $<$ htpp://www.portal.unesco.org.

UNIDADES AMBIENTAIS DO RECIFE. Prospecto da Prefeitura do Recife. Recife: Secretaria de Planejamento, Urbanismo e Meio Ambiente, 1993.

VASCONCELOS, Ronald; BEZERRA, Onilda (Orgs.). Atlas ambiental do Recife: Recife: Prefeitura da cidade do Recife/ Secretaria de Planejamento, Urbanismo e Meio Ambiente, 2000. 
